Editorial

\title{
Strategies, Advances, and Challenges in Breeding Perennial Grain Crops
}

\author{
Timothy E. Crews ${ }^{1, *}$ and Douglas J. Cattani ${ }^{2}$ (D) \\ 1 The Land Institute, 2440 E. Water Well Rd., Salina, KS 67401, USA \\ 2 Department of Plant Science, University of Manitoba, 66 Dafoe Road, Winnipeg, MB R3T 2N2, Canada; \\ Doug.Cattani@umanitoba.ca \\ * Correspondence: crews@landinstitute.org; Tel.: +1-785-823-5376
}

Received: 14 June 2018; Accepted: 16 June 2018; Published: 27 June 2018

\begin{abstract}
The development of new perennial crop species is gaining momentum as a promising approach to change the fundamental nature of ecosystem processes in agriculture. The ecological argument for perennial crops grown in polycultures is strong, but until recently, perennial herbaceous grain crops have been absent from agricultural landscape. This is not because perennial herbaceous species do not exist in nature-there are thousands of perennial grasses, legumes, and other broad leaf plants. Rather, for a variety of reasons, early farmers focused on cultivating and domesticating annuals, and the perennial herbs were largely ignored. Today, we have a tremendous opportunity to explore another agricultural path. Building on contemporary knowledge of plant biology and genetics that early farmers lacked, and using a rapidly expanding toolbox that includes sophisticated genomic and analytical approaches, we can develop viable perennial grain crops. These crops can then be used to assemble diverse agroecosystems that regenerate soils and capture other important ecosystem functions.
\end{abstract}

Keywords: perennial; cereal; legume; pulse; oilseed; crop diversity; plant breeding; genetics; ecosystem services

\section{Introduction}

Numerous papers have been published over the last decade describing predicted improvements in soil carbon balance, nutrient retention, soil water uptake efficiency, soil microbiome functions, and weed suppression, as annual crops that require soil disturbance and/or frequent exposure to maintain are replaced by perennial crops that require minimal soil disturbance or periods of exposure [1-7]. Other papers have addressed questions of why humans originally domesticated annual grain crops and what strategies make sense for domesticating new perennial grain crop species [8-11]. Relatively few papers, however, have been published that provide current overviews of progress in breeding specific perennial crops. The last significant progress report on this subject was a Proceedings of a Food and Agriculture Organization (FAO)-sponsored meeting that took place in Rome in 2013 [12]. Every new crop species is unique in where it is situated in the breeding pipeline, the nature of genetic challenges it faces, the traits that require breeding attention, and the progress made in breeding improvements to date. This Special Issue of Sustainability is dedicated to providing up-to-date reports on many works in progress, what lessons have been learned, and how strategies to breed perennial grain crops have been reinforced or modified based on experience using conventional breeding methods as well as new molecular or cytogenetic tools. 


\section{Background}

There is good evidence that humans began consuming the seeds of numerous wild grasses over 23,000 years BP [13] and some evidence that our consumption of cereals began over 100,000 years ago [14]. The relationship between humans and cereals gradually transitioned from facultative to obligate with the domestication of annual grass species, including rice, wheat, barley, maize, millet, and sorghum, in at least six centers of origin around the world 5-10,000 years BP [15]. In addition to grass seeds, pulses or seed-crop legumes such as beans or lentils were also domesticated in the same major centers of crop domestication $[15,16]$. With domestication, the symbiosis between humans and annual cereal, pulse, and oilseed crops, or collectively grains, became spectacularly successful.

The question of why humans gradually shifted from a diet of hunted and foraged foods to one based heavily on cultivated annual grains has been visited and re-visited by geographers, anthropologists, archaeologists, geneticists, and agronomists $[15,17,18]$. Theories commonly weave together multiple factors such as food shortages, climate change, resource degradation, grain storage, and changing socio-economic structures associated with a more sedentary lifestyle. Yet importantly, ecological sustainability is absent from the list of possible reasons why humans committed to becoming farmers of annual grains. Indeed, the conversion of natural ecosystems characterized by diverse perennial vegetation to agroecosystems that rely on frequent elimination of all vegetation to establish annual grain species has committed us to a food procurement strategy that is decidedly precarious. History is replete with examples of annual grain production resulting in extreme soil degradation which became a primary driver of social collapse [19-22]. Furthermore, in spite of large investments and sweeping campaigns to halt soil erosion and degradation over the last century, a 2015 FAO report involving over 200 soil scientists from around the world concluded:

while there is cause for optimism in some regions, the overwhelming conclusion from the regional assessments is that the majority of the world's soil resources are in only fair, poor or very poor condition. The most significant threats to soil function at the global scale are soil erosion, loss of soil organic carbon and nutrient imbalance. The current outlook is for this situation to worsen unless concerted actions are taken by individuals, the private sector, governments and international organizations. [23]

Losing the soil resource through erosion as a consequence of attempting to grow enough annual grains to satisfy humanity's dietary demands poses a long-term existential threat to our species. However, erosion is not the only ecosystem disservice that results from our conversion of high diversity perennial ecosystems to low diversity annual agroecosystems [24]. The specific ecosystem disservices listed in Figure 1 have all received piecemeal attention by the agricultural research community. Many input and capital-intensive strategies for improvement in agriculture, such as nitrification inhibitors, variable rate fertilizer application, and patented, genetically engineered herbicide tolerant crops, have been advanced. While often effective at easing specific ecosystem disservices, these and other solutions further commit farmers to a technological treadmill that directs wealth away from their farms to the producers and marketers of machinery and inputs. An alternative approach to addressing the ecosystem disservices listed in Figure 1 is to fundamentally alter the agricultural ecosystem itself. By perennializing crop species, and increasing crop diversity at the field, farm, and regional scale, there is good reason to expect many ecosystem services delivered by the natural ecosystems that predated agriculture to be recovered (Figure 1). 


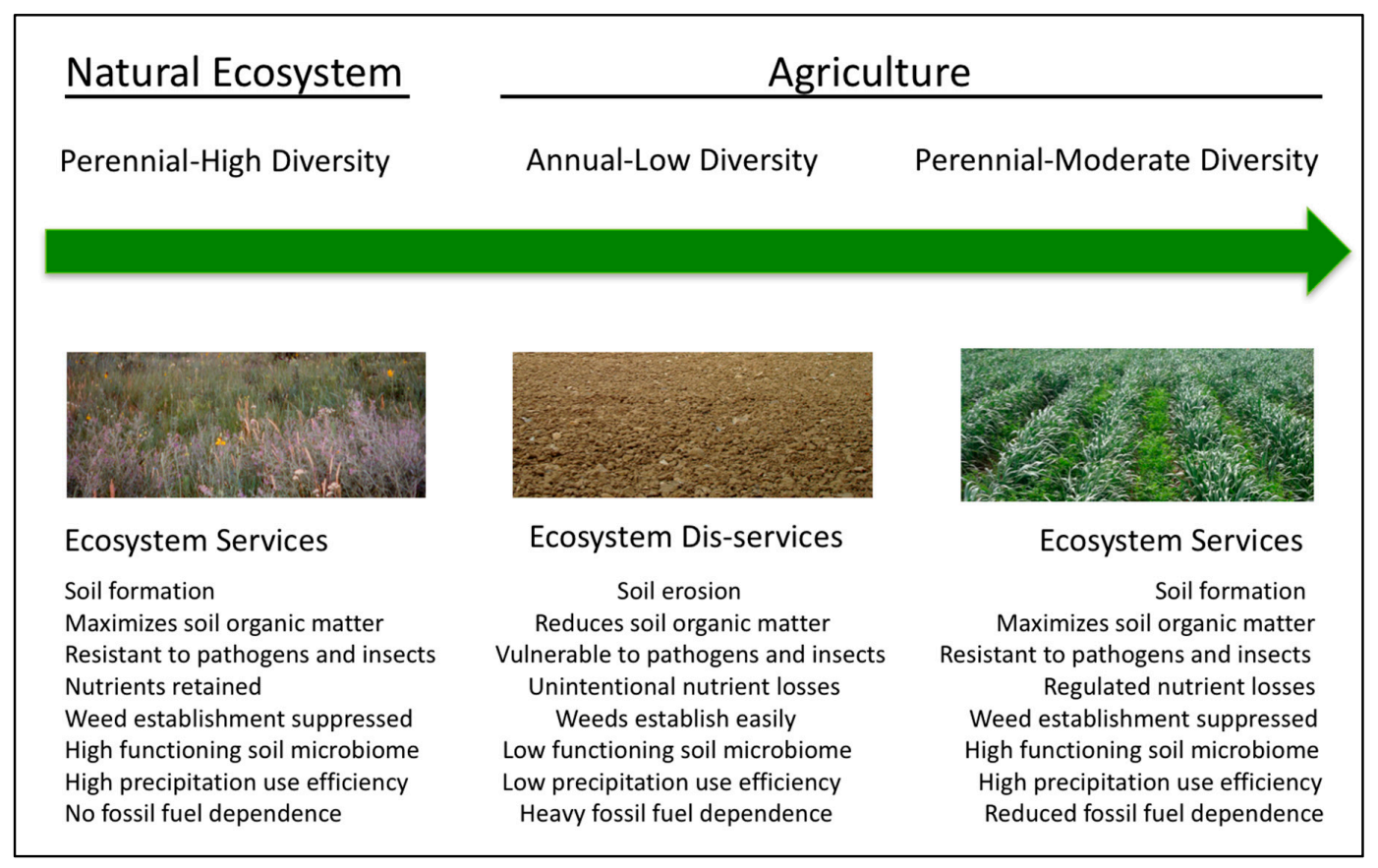

Figure 1. When natural ecosystems such as a prairie are converted to annual grain ecosystems, key services commonly degrade into disservices. The development of diverse perennial grain agriculture has the potential to reestablish many of the ecosystem services that were supported by the original natural ecosystem [24].

\section{Breeding Perennial Grains}

There are two basic approaches currently employed to develop new perennial grain crops. The first is de novo or direct domestication, and the second is wide hybridization $[25,26]$. Virtually all of the annual grains that humans currently consume were developed through domestication. In brief, Neolithic peoples identified desirable wild plant species and subjected them to cycles of selection that favored "domestication" traits such as non-shattering (retaining seeds in seed heads until harvest), or uniform maturation of seed both on individual plants and across plant populations [9]. Once domestication traits were well established or "fixed" in populations, farmers were able to practice phenotypic selection to improve on seed yield and other desirable crop traits. With the advent of modern plant genetics, crop breeders still relied on phenotypic selection, but their work was informed by a new, complex understanding of genetic and environmental interactions. Today, several breeding programs are beginning to employ some degree of genomic selection that eliminates the need for phenotypic evaluation every selection cycle.

The second approach to developing perennials is to cross existing high-yielding annual grains with related, usually wild, perennial species either in the same genus or tribe with the goal of introgressing the genes that confer perennialism into the annual species. Wide hybridization is attractive because, if successful, the new hybrid species can largely inherit highly developed traits such as yield and end-use quality from the already domesticated annual parent. Challenges arise, however, when the chromosome sets (genomes) or number of chromosome sets (ploidy level) in the annual and perennial parents do not match and/or do not recombine during meiosis (see, for example, papers by Cox et al. [27] and Hayes et al. [28] in this volume).

In this special issue, reports on de novo domestication projects include intermediate wheatgrass (Thinopyrum intermedium), which produces a grain similar to wheat called Kernza ${ }^{\circledR}[29,30]$, silflower (Silphium integrifolium), a member of the sunflower family under development as an oilseed crop [31,32], and perennial barley (Hordeum spp.) [33]. The issue also includes a review focusing on species in the legume family under consideration for domestication as pulse crops [34]. Progress on developing 
perennial grains through wide hybridization is described in reports on sorghum (Sorghum bicolor $\times$ S. halepense) [27], wheat (Triticum spp. $\times$ Thinopyrum spp.) [28], rice (Oryza sativa $\times$ O. longistaminata) [35], and buckwheat (Fagopyrum spp. $\times$ Fagopyrum spp.) [36]. All of these perennial crops under development, whether products of hybridization or domestication strategies, rely on conventional plant breeding techniques such as mass selection, pure line selection, pedigree, bulk population, single seed descent, backcrossing, multiline, and composite approaches. In recent decades, many plant breeders and geneticists, including those working on perennial grains, have taken advantage of new molecular and cytogenetic techniques that have improved, and in some cases revolutionized conventional breeding approaches (Table 1). Each perennial grain crop featured in this special issue reflects a unique strategy involving particular conventional and molecular or cytogenetic methodologies.

Table 1. Conventional, molecular, and cytogenetic plant breeding techniques discussed in one or more papers of this special issue on breeding perennial grain crops.

\begin{tabular}{|c|c|c|}
\hline Technique & Abbreviation & Description \\
\hline Embryo rescue & & $\begin{array}{l}\text { A method of in vitro culture that helps facilitate the } \\
\text { development of plant embryos that may not survive otherwise, } \\
\text { such as those from wide-hybrid crosses. }\end{array}$ \\
\hline Genome editing & & $\begin{array}{l}\text { Using site-directed approaches to introduce DNA lesions, insert } \\
\text { foreign DNA sequences, or delete DNA segments at specific } \\
\text { locations in the genome. }\end{array}$ \\
\hline $\begin{array}{l}\text { Genome-wide } \\
\text { association studies }\end{array}$ & GWAS & $\begin{array}{l}\text { Studies that observe a set of genome-wide genetic variants or } \\
\text { markers to determine if any marker(s) are associated with a trait } \\
\text { of interest. These associations can be used in MAS. }\end{array}$ \\
\hline Genomic selection & GS & $\begin{array}{l}\text { Selection for quantitative traits using genomic estimated } \\
\text { breeding values based on genome-wide markers in a population. } \\
\text { GS reduces the frequency of phenotyping and increases annual } \\
\text { gains by reducing breeding cycle time. }\end{array}$ \\
\hline $\begin{array}{l}\text { Genomic in situ } \\
\text { hybridization }\end{array}$ & GISH & $\begin{array}{l}\text { A cytogenetic technique that allows scientists to radiolabel parts } \\
\text { of the genome within cells. It can be used to study meiosis, } \\
\text { perform comparative genomic studies, and identify } \\
\text { chromosomal inheritance in wide-hybrid crosses. }\end{array}$ \\
\hline $\begin{array}{l}\text { High-throughput } \\
\text { genotyping }\end{array}$ & HTPG & $\begin{array}{l}\text { Efficient methods for simultaneous DNA marker discovery and } \\
\text { genotyping in many samples. }\end{array}$ \\
\hline $\begin{array}{l}\text { Marker assisted } \\
\text { selection }\end{array}$ & MAS & $\begin{array}{l}\text { A marker-based method for selection of plants with the desired } \\
\text { allele(s) from the donor parent(s) at a major gene, generally for } \\
\text { qualitative traits. }\end{array}$ \\
\hline Mutagenesis & & $\begin{array}{l}\text { A random or targeted process to create heritable variation for a } \\
\text { trait of interest by inducing DNA lesions when sufficient } \\
\text { variation does not occur in natural populations. }\end{array}$ \\
\hline Quantitative trait locus & QTL & $\begin{array}{l}\text { A region of the genome that correlates with variation in a } \\
\text { phenotype. Usually the region is linked to or contains genes that } \\
\text { control the phenotype. Can be used in MAS. }\end{array}$ \\
\hline $\begin{array}{l}\text { Single nucleotide } \\
\text { polymorphism }\end{array}$ & SNP & $\begin{array}{l}\text { A variation at a single position (nucleotide) in a DNA sequence } \\
\text { among individuals that can be used as a genetic marker. It is the } \\
\text { most common type of genetic variation occurring throughout } \\
\text { the genome. }\end{array}$ \\
\hline
\end{tabular}

\section{Expanding Global Effort}

Work on perennial grain agriculture is taking place in more institutions around the world than ever before (Figure 2). This work draws from the disciplines of agronomy, ecology, ethnobotany, evolutionary biology, genetics, microbiology, plant breeding, plant pathology, physiology, sociology, and others. As promising as this expansion is, we hope that this special issue of Sustainability will 
inspire more plant breeders and geneticists to initiate new perennial crop breeding programs. The level of intra- and interspecific diversity needed to achieve the ecological intensification described above is far greater than can be provided with the crops under development today. Opportunities exist to develop more perennial crops through wide hybridization, as numerous annual grain or row crops such as corn, cotton, oat, soybean, and chickpea have closely related wild perennial relatives [37]. A far greater number of domestication candidates exist in the wild, and considerable thought has gone into strategic breeding approaches for this group [10]. In an effort to begin cataloging and prioritizing candidates for de novo domestication, Miller, Ciotir, Applequist, and colleagues at Saint Louis University (USA) in conjunction with the Missouri Botanical Garden and The Land Institute have launched the "Global Inventory and Systematic Evaluation of Perennial Grain, Legume, and Oilseed species for Pre-breeding and Domestication." The database is under development and is accessible through the Missouri Botanical Garden's Tropicos Website [38]. This searchable database includes names and specimen information for all known perennial herbaceous grasses (7636 species) and perennial herbaceous legumes (6746 species). Ethnobotanical, toxicological, and trait data are being compiled and entered into the database and species of interest are being grown out in "candidate" gardens. This botanical foundation will help to facilitate the development of new "hardware" in the form of perennial crops needed to achieve the level of ecological intensification that is possible, and necessary, as the human population approaches eight billion. Decades will be required to create new, viable crop species, even when employing the latest molecular and cytogenetic tools. However, the return on investment could contribute substantially to assuring the sustainability of agriculture over the next 10,000 years.

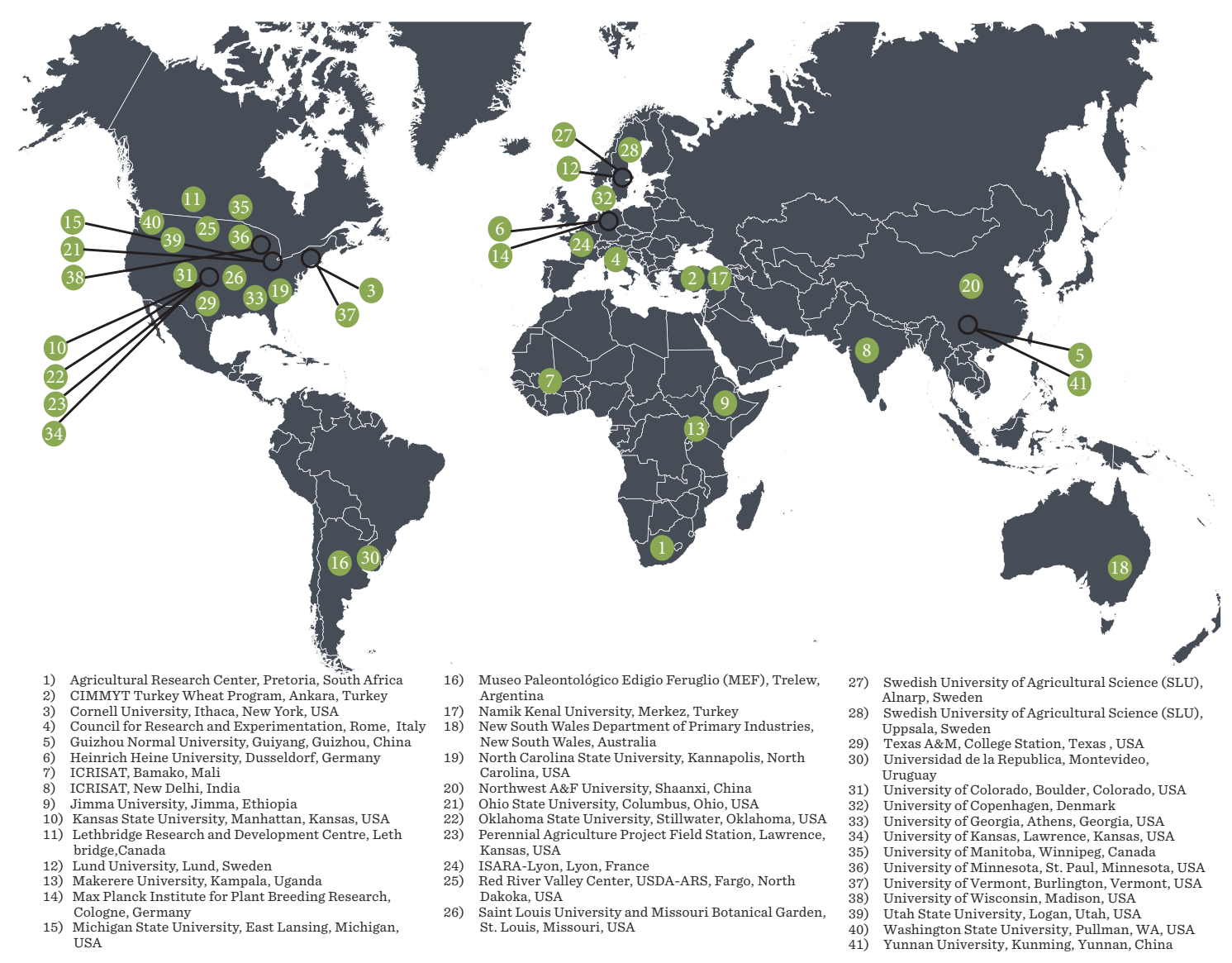

Figure 2. Map showing home institutions of many of the research groups working on the development of perennial grain agroecosystems. 
Funding: Crews acknowledges support from the Perennial Agriculture Project, a joint project between The Land Institute and the Malone Family Land Preservation Foundation. Cattani acknowledges support from the government of Manitoba, the Faculty of Agricultural and Food Sciences, and the Department of Plant Science of the University of Manitoba.

Acknowledgments: The authors thank Brandon Schlautman and Allison Miller for their helpful contributions to this editorial.

Conflicts of Interest: The authors declare no conflict of interest.

\section{References}

1. Glover, J.D.; Culman, S.W.; DuPont, S.T.; Broussard, W.; Young, L.; Mangan, M.E.; Mai, J.G.; Crews, T.E.; DeHaan, L.R.; Buckley, D.H.; et al. Harvested perennial grasslands provide ecological benchmarks for agricultural sustainability. Agric. Ecosyst. Environ. 2010, 137, 3-12. [CrossRef]

2. Crews, T.E.; Blesh, J.; Culman, S.W.; Hayes, R.C.; Steen Jensen, E.; Mack, M.C.; Peoples, M.B.; Schipanski, M.E. Going where no grains have gone before: From early to mid-succession. Agric. Ecosyst. Environ. 2016, 223, 223-238. [CrossRef]

3. Crews, T.E.; Rumsey, B.E. What agriculture can learn from native ecosystems in building soil organic matter: A review. Sustainability 2017, 9, 578. [CrossRef]

4. Culman, S.W.; Snapp, S.S.; Ollenburger, M.; Basso, B.; DeHaan, L.R. Soil and water quality rapidly responds to the perennial grain Kernza wheatgrass. Agron. J. 2013, 105, 735-744. [CrossRef]

5. Baker, B. Can modern agriculture be sustainable? Bioscience 2017, 67, 325-331. [CrossRef]

6. Li, N.; Yao, S.H.; You, M.Y.; Zhang, Y.L.; Qiao, Y.F.; Zou, W.X.; Han, X.Z.; Zhang, B. Contrasting development of soil microbial community structure under no-tilled perennial and tilled cropping during early pedogenesis of a Mollisol. Soil Biol. Biochem. 2014, 77, 221-232. [CrossRef]

7. Weißhuhn, P.; Reckling, M.; Stachow, U.; Wiggering, H. Supporting Agricultural Ecosystem Services through the Integration of Perennial Polycultures into Crop Rotations. Sustainability 2017, 9, 2267. [CrossRef]

8. Cox, T. Crop domestication and the first plant breeders. In Plant Breeding and Farmer Participation; Ceccarelli, S., Guimaraes, E.P., Weltizien, E., Eds.; FAO: Rome, Italy, 2009; pp. 171-193.

9. Van Tassel, D.L.; DeHaan, L.R.; Cox, T.S. Missing domesticated plant forms: Can artificial selection fill the gap? Evol. Appl. 2010, 3, 434-452. [CrossRef] [PubMed]

10. DeHaan, L.R.; Van Tassel, D.L.; Anderson, J.A.; Asselin, S.R.; Barnes, R.; Baute, G.J.; Cattani, D.J.; Culman, S.W.; Dorn, K.M.; Hulke, B.S.; et al. A pipeline strategy for grain crop domestication. Crop Sci. 2016, 56, 917-930. [CrossRef]

11. Kantar, M.B.; Tyl, C.E.; Dorn, K.M.; Zhang, X.; Jungers, J.M.; Kaser, J.M.; Schendel, R.R.; Eckberg, J.O.; Runck, B.C.; Bunzel, M.; et al. Perennial Grain and Oilseed Crops. Annu. Rev. Plant Biol. 2016, 67, 703-729. [CrossRef] [PubMed]

12. Batello, C.; Wade, L.; Cox, S.; Pogna, N.; Bozzini, A.; Choptiany, J. Perennial Crops for Food Security: Proceedings of the FAO Expert Workshop; Proceedings of the Perennial Crops for Food Security Proceedings of the FAO Expert Workshop; FAO: Rome, Italy, 2013.

13. Weiss, E.; Wetterstrom, W.; Nadel, D.; Bar-Yosef, O. The broad spectrum revisited: Evidence from plant remains. Proc. Natl. Acad. Sci. USA 2004, 101, 9551-9555. [CrossRef] [PubMed]

14. Mercader, J. Mozambican grass seed consumption during the Middle Stone Age. Science 2009, 326, 1680-1683. [CrossRef] [PubMed]

15. Gepts, P. Selection Experiment. Plant Breed. Rev. 2004, 24, 1-44.

16. Harlan, J.R. Crops \& Man; American Society of Agronomy: Madison, WI, USA, 1992; 269p.

17. Cohen, M.N. Introduction: Rethinking the Origins of Agriculture. Curr. Anthropol. 2009, 50, 591-595. [CrossRef] [PubMed]

18. Harlan, J.R. The Living Fields; Cambridge University Press: Cambridge, UK, 1995; 273p.

19. Carter, V.G.; Dale, T. Topsoil and Civilization; University of Oklahoma Press: Norman, OK, USA, 1955; 292p.

20. Hillel, D. Out of the Earth: Civilization and the Life of the Soil; University of California Press: Berkeley, CA, USA, 1992.

21. Montgomery, D.R. Dirt: The Erosion of Civilizations; University of California Press: Berkeley, CA, USA, 2007; $285 p$. 
22. Gomiero, T. Soil degradation, land scarcity and food security: Reviewing a complex challenge. Sustainability 2016, 8, 281. [CrossRef]

23. Food and Agriculture Organization of the United Nations. Status of the World's Soil Resources: Technical Summary [Internet]. 2015. Available online: http:/ / www.fao.org/documents/card/en/c/c6814873-efc341db-b7d3-2081a10ede50/ (accessed on 23 June 2018).

24. Crews, T.E.; Carton, W.; Olsson, L. Is the future of agriculture perennial? Glob. Sustain. 2018, in press.

25. Wagoner, P.; Schaeffer, J.R. Perennial grain development: Past efforts and potential for the future. CRC Crit. Rev. Plant Sci. 1990, 9, 381-408. [CrossRef]

26. Cox, T.S.; Bender, M.; Picone, C.; Van Tassel, D.L.; Holland, J.B.; Brummer, E.C.; Zoeller, B.E.; Paterson, A.H.; Jackson, W. Breeding perennial grain crops. CRC Crit. Rev. Plant Sci. 2002, 21, 59-91. [CrossRef]

27. Cox, S.; Nabukalu, P.; Paterson, A.; Kong, W.; Nakasagga, S. Development of Perennial Grain Sorghum. Sustainability 2018, 10, 172. [CrossRef]

28. Hayes, R.C.; Wang, S.; Newell, M.T.; Turner, K.; Larsen, J.; Gazza, L.; Anderson, J.A.; Bell, L.W.; Cattani, D.J.; Frels, K.; et al. The performance of early-generation perennial winter cereals at 21 sites across four continents. Sustainability 2018, 10, 1124. [CrossRef]

29. Cattani, D.J. Has Selection for Grain Yield Altered Intermediate Wheatgrass? Sustainability 2018, 10, 688. [CrossRef]

30. DeHaan, L.; Christians, M.; Crain, J.; Poland, J. Development and evolution of an intermediate wheatgrass domestication program. Sustainability 2018, 10, 1499. [CrossRef]

31. Vilela, A.; González-Paleo, L.; Turner, K.; Peterson, K.; Ravetta, D.; Crews, T.; Van Tassel, D. Progress and Bottlenecks in the Early Domestication of the Perennial Oilseed Silphium integrifolium, a Sunflower Substitute. Sustainability 2018, 10, 638. [CrossRef]

32. Turner, M.; Ravetta, D.; Van Tassel, D. Effect of Puccinia silphii on Yield Components and Leaf Physiology in Silphium integrifolium: Lessons for the Domestication of a Perennial Oilseed Crop. Sustainability 2018, 10, 696. [CrossRef]

33. Westerbergh, A.; Lerceteau-Köhler, E.; Sameri, M.; Bedada, G.; Olof-Lundquist, P. Towards the Development of Perennial Barley for Cold Temperate Climates-Evaluation of Wild Barley Relatives as Genetic Resources. Sustainability 2018, 10, 1969. [CrossRef]

34. Schlautman, B.; Miller, A.J. Perennial Grain Legume Domestication Phase I: Criteria for Candidate Species Selection. Sustainability 2018, 10, 730. [CrossRef]

35. Huang, G.; Qin, S.; Zhang, S.; Cai, X.; Wu, S.; Dao, J.; Zhang, J.; Huang, L.; Harnpichitvitaya, D.; Wade, L.; et al. Performance, economics and potential impact of perennial rice PR23 relative to annual rice cultivars at multiple locations in Yunnan Province of China. Sustainability 2018, 10, 1086. [CrossRef]

36. Chen, Q.-F.; Huang, X.-Y.; Li, H.-Y.; Yang, L.-J.; Cui, Y.-S. Recent Progress in Perennial Buckwheat Development. Sustainability 2018, 10, 536. [CrossRef]

37. Cox, T.S.; Glover, J.D.; Van Tassel, D.L.; Cox, C.M.; Dehaan, L.R. Prospects for Developing Perennial Grain Crops. Bioscience 2006, 56, 649-659. [CrossRef]

38. Miller, A.; Applequist, W.; Ciotir, C. Global Inventory and Systematic Evaluation of Perennial Grain, Legume, and Oilseed Species for Pre-breeding and Domestication. 2016. Available online: http:/ /www.tropicos.org/ projectwebportal.aspx?pagename=Introduction\&projectid $=80$ (accessed on 24 February 2018).

(C) 2018 by the authors. Licensee MDPI, Basel, Switzerland. This article is an open access article distributed under the terms and conditions of the Creative Commons Attribution (CC BY) license (http://creativecommons.org/licenses/by/4.0/). 